\title{
CUT CYCLES AND SOIL CARBON POTENTIAL STOCKS IN A MANAGED FOREST IN THE CAATINGA DOMAIN IN BRAZIL ${ }^{1}$
}

\author{
JOSÉ FRÉDSON BEZERRA LOPES ${ }^{2 *}$, EUNICE MAIA DE ANDRADE ${ }^{3}$, ERICH CELESTINO BRAGA PEREIRA ${ }^{4}$, \\ DIEGO ANTUNES CAMPOS ${ }^{4}$, DEODATO DO NASCIMENTO AQUINO ${ }^{2}$
}

\begin{abstract}
Management of tropical dry forests in Brazil expanded 450\% in the two latest decades; but little is known about the dynamics of these areas. Thus, the objective of this work was to evaluate if the recovery of mean original biomass stocks (MOBS) is a consistent criterion to define cut cycles in a managed forest for charcoal production, and determine the remaining biomass and its contribution to soil carbon stocks. The study was conducted at the Ramalhete Settlement, in General Sampaio, CE, Brazil, in 2018. The explorable shrubby-arboreous biomass (ESAB) and the ESAB mean annual increases (ESAB-MAI) were determined in five areas subjected to clearcutting after $3,5,8,11$, and 15 years, and in a preservation area with 40 years of regeneration. Each area was divided into seven plots $(20 \times 20 \mathrm{~m})$, totaling 42 plots. The ESAB of the plots were compared and the remaining biomass (branches, stumps, and litterfall) in a recently explored area was calculated and converted into organic carbon. The remaining biomass of branches had higher contribution to soil carbon stocks, followed by the litterfall, and stumps. The carbon stocks of the branch component were 3.4-fold higher than those of the litterfall. The recovery of the MOBS of an area after clearcutting should not be used as a criterion to define the cut cycle, since these original carbon stocks do not represent the maximum ESAB production possible in the area; the biodiversity and amount of ESAB in the classes of larger diameter are more adequate criteria.
\end{abstract}

Keywords: Tropical dry forest. Caatinga phytogeographic domain. Plant biomass. Regeneration. Forest residues.

\section{CICLOS DE CORTE E POTENCIAL APORTE DE CARBONO AO SOLO EM MANEJO FLORESTAL DA CAATINGA}

\begin{abstract}
RESUMO - O manejo florestal na floresta tropical seca do Brasil expandiu em 450\% nas duas últimas décadas; mas pouco se sabe da dinâmica nessas áreas. Assim, em uma área manejada para produção de carvão, objetivou-se avaliar se a recuperação dos estoques originais médios de biomassa (EOMB) é um critério consistente para definir ciclos de corte, além disso, determinou-se a biomassa remanescente e seu potencial de aporte de carbono ao solo. O estudo foi realizado no Assentamento Ramalhete, General Sampaio-CE, no ano de 2018. Determinou-se a biomassa arbustiva-arbórea explorável (BAAE) e o incremento médio anual (IMA) em cinco talhões submetidos ao corte raso há 3, 5, 8, 11 e 15 anos, e reserva legal (40 anos em regeneração). Em cada talhão foram instaladas sete parcelas $(20,0 \mathrm{~m}$ x 20,0 m), totalizando 42 parcelas amostrais. Comparou-se a BAAE com a de projeto e calculou-se a biomassa remanescente (ramos, cepas e serapilheira) em um talhão recém explorado, a qual foi convertida para carbono orgânico. Quanto à biomassa remanescente, a ordem de maior potencial de aporte de carbono ao solo foi ramos $>$ serapilheira $>$ cepas. $\mathrm{O}$ aporte oriundo do componente ramos é superior ao da serapilheira em 3,4 vezes. A simples recuperação dos EOMB de um talhão após o corte raso não serve como critério para se definir um novo ciclo de corte, pois esses estoques originais não representam a máxima BAAE possível para essa área; sendo a biodiversidade e a presença de mais BAAE nas classes de maior diâmetro critérios mais adequados.
\end{abstract}

Palavras-chave: Floresta tropical seca. Domínio Fitogeográfico da Caatinga. Biomassa vegetal. Regeneração. Resíduos florestais.

\footnotetext{
${ }^{*}$ Corresponding author

${ }^{1}$ Received for publication in $10 / 09 / 2019$; accepted in $03 / 25 / 2020$.

Paper extracted from the master's thesis of the first author.

${ }^{2}$ Division of development and Consolidation of Settlement Project, Instituto Nacional de Colonização e Reforma Agrária, Fortaleza, CE, Brazil; fredsonbezerra26@gmail.com - ORCID: 0000-0003-4992-5314, deoagro@hotmail.com - ORCID: 0000-0002-2736-5136.

${ }^{3}$ Department of Soil and Water Conservation, Universidade Federal Rural do Semi-Árido, Mossoró, RN, Brazil; eandrade.ufc@gmail.com - ORCID: 0000-0002-9750-0364.

${ }^{4}$ Department of Agricultural Engineering, Universidade Federal do Ceará, Fortaleza, CE, Brazil; erichpos0@gmail.com - ORCID: 00000002-6599-1779, antunes.diego@gmail.com - ORCID: 0000-0001-8603-7223.
} 


\section{INTRODUCTION}

The area of dry ecosystems is estimated in $41.5 \%$ of Earth's surface (SORENSEN, 2009) and, according to the recent simulation models, climatic changes can increase them in $11 \%$ to $23 \%$ up to the end of the $21^{\text {st }}$ century (HUANG et al., 2015). Tropical dry forests (TDF) are part of these ecosystems and are found in all continents, covering an area of $1.05^{6} \mathrm{~km}^{2}$. The two greatest areas are in South America, one in the Northeast of Brazil and other in Southwest of Bolivia, Paraguay, and North of Argentina (MILES et al., 2006). The Brazilian one is covered with TDF known as Caatinga phytogeographic domain (CPD); it covers an area of approximately $844,453 \mathrm{~km}^{2}$ and is home to a population of 27 million people. The CPD is classified as the most populous semiarid region of the world (MORO et al., 2016).

Forest exploration has increased in this region through management projects, since this activity is less susceptible to the local climatic adversities. These managements include the discarding of residues (not used plant parts); however, little information about quantity of residues produced is found, only one study was found, which is based on secondary data (LOPES; ANDRADE, 2017). Moreover, information on possible benefits of these residues and how they affect soil geochemical properties in managed areas of TDF-CPD is not found. However, the use of forest residues such as branches for energetic purposes have been studied for other natural and planted forests (BRAZ et al., 2014; CRUZ FILHO, SILVA, 2009), and benefits to soil have been found for pine plantations (WEBSTER et al., 2016).

In addition, there are no defined criteria for cut cycle or consensus on the correct time for new exploration of the area, which vary between 8 and 20 years, resulting in high heterogeneity of estimates (RIEGELHAUPT; PAREYN; GARIGLIO, 2010). A fixed cycle of 15 years is usually used, however, a decrease to 12 years has been considered for the state of Ceará in Brazil. One of the questionable criteria is that a new cut can be done when the biomass of the area is recovered to the levels found at the implementation stage in the initial survey, since the succession stage of the area at implementation is not known. In the case of young areas, at the $3^{\text {rd }}$ or $4^{\text {th }}$ stage of secondary progressive succession, one can assume the stocks as the maximum possible for the site, thus assuming that the vegetation had reached stability (RIEGELHAUPT; PAREYN; GARIGLIO, 2010). Araújo Filho (2013) reported that 45 to 50 years is needed for the shrubby-arboreous stage of the TDF-CPD be predominantly arboreous. A higher energetic efficiency due to a higher calorific power is related to greater stem diameters (YAN; XU; HE, 2018; ZENG; TANG; XIAO, 2014), whose formation are dependent on the regeneration time. Thus, the current criteria adopted to define cut cycles for TDF-CPD are not enough for the biomass and biodiversity recovery.

In this context, the objective of this work was to evaluate if the recovery of mean original biomass stocks is a consistent criterion to define cut cycles, and determine the remaining biomass and its contribution to soil carbon stocks.

\section{MATERIAL AND METHODS}

The study was conducted from January to March 2018 in an area with managed forest under agrosilvopastoral system, which used clearcutting. This area is part of the Ramalhete Settlement Project, in the municipality of General Sampaio, state of Ceará, Brazil (Figure 1). The Settlement has an area of 890.10 ha, 431.23 ha intended to management projects and 178.22 ha are preservation areas. The forest management begun in 2002.

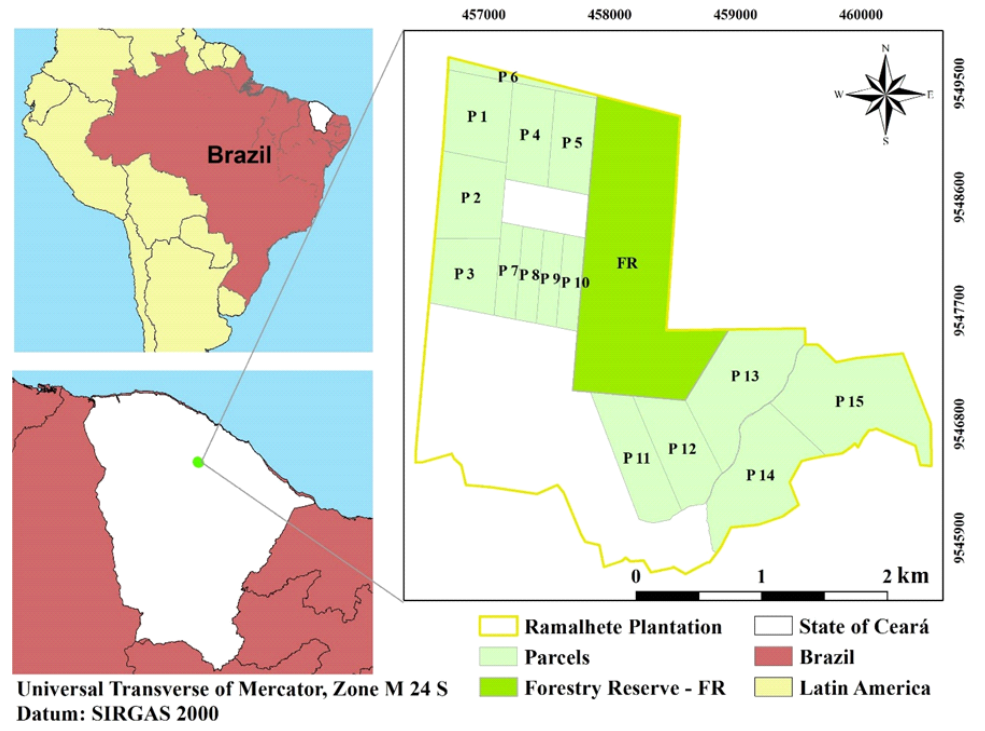

Figure 1. Location of the Ramalhete Settlement Project, municipality of General Sampaio, state of Ceará, Brazil.

Rev. Caatinga, Mossoró, v. 33, n. 3, p. 735 - 745, jul. - set., 2020 
The climate of the region is BSh'w', semiarid hot, according to the Köppen classification, with mean monthly temperature above $18{ }^{\circ} \mathrm{C}$, predominant rainfall in the autumn, with mean depth of $744 \mathrm{~mm}$, potential evapotranspiration of 1556 $\mathrm{mm}$, and aridity index of 0.48 . The region presents high rainfall spatial and temporal variability (ANDRADE et al., 2016). The soils predominant in the region are Planosols, Luvisols and Argisols and the vegetation was characterized as shrubbyarboreous dense Caatinga (VERDE VIDA, 2010).

The history of the area described in Figure 2, which shows the land use before part of it became a preservation area, the year of creation of the preservation area, year of creation of the forest management project, and dates of interventions in each sampled area.

Preserved area: area in regeneration for 40 years, which had its vegetation cut, and used for maize, bean, and cotton crops. This area had been used for grazing cattle (bovine, ovine, and caprine) without overgrazing, according to the local farmers.

Parcels in regeneration: areas in regeneration for 3 (T3), 5 (T10), 8 (T9), 11 (T4) and 15 (T1) years. These areas were subjected to clearcutting as shown in Figure 2; all the wood that could be processed for charcoal production was extracted. The exploration residues (branches) were distributed in piles on the land (Figure 3). These areas also had been used for grazing cattle (bovine, ovine, and caprine) without overgrazing, according to the local farmers.

Recently explored area: area in which the aerial part of the plants was removed in February 2018 (T12) for charcoal production, remaining some biomasses (branches and stumps).

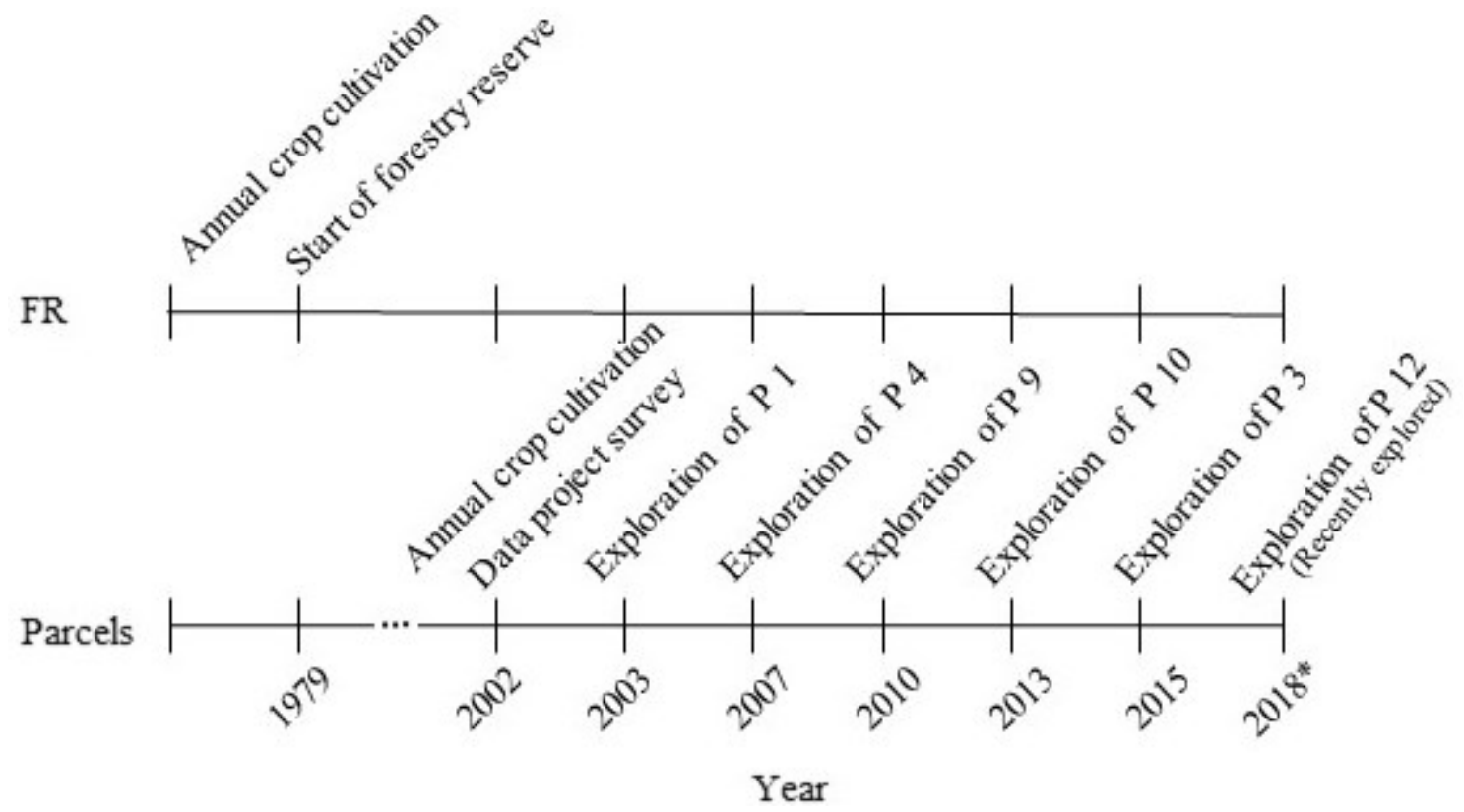

Figure 2. History line of interventions of the study area. *field sampling.

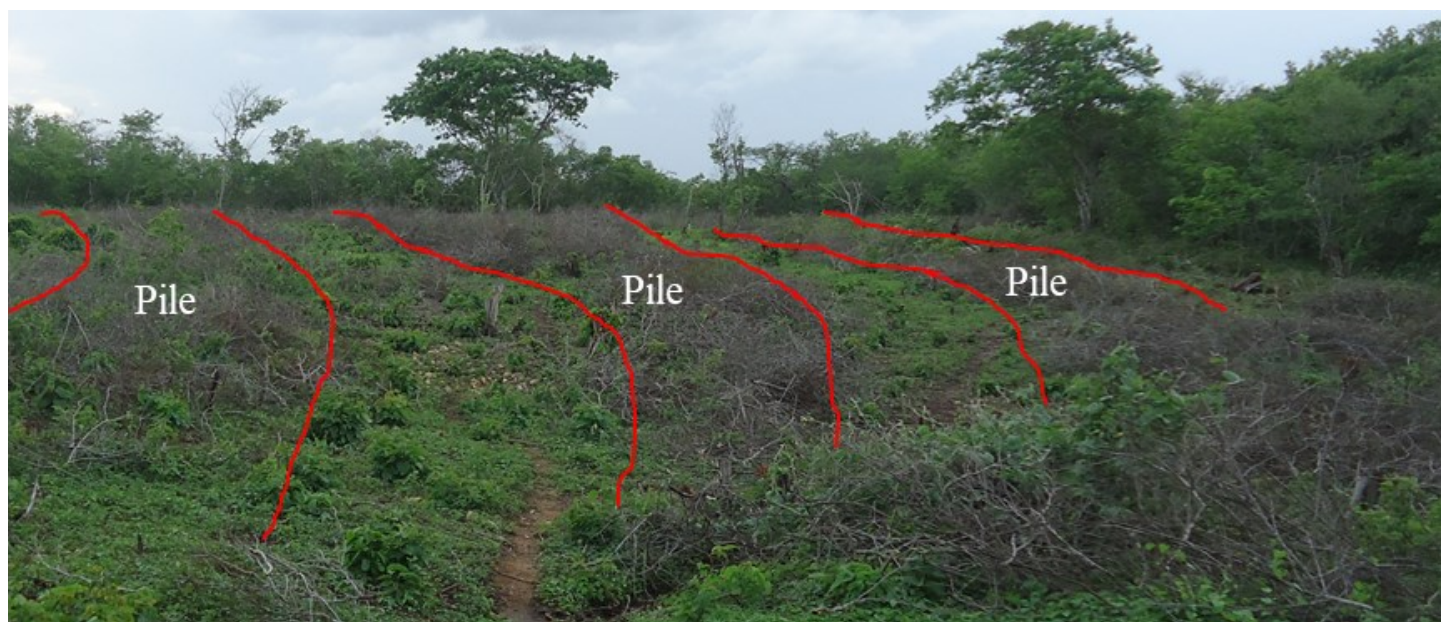

Figure 3. Piles of residues (branches) formed by the forest exploration. 
The research was done in three phases: a) sampling of explorable shrubby-arboreous biomass $(\mathrm{ESAB})$ in areas in regeneration and in a preservation area (PA); b) determination of the remaining biomass in a recently explored area; and c) estimating of the contribution of the remaining biomass to soil carbon stocks (remaining biomass in the area after the exploration).

The first stage was carried out in five areas in regeneration and in the PA (treatments). Each area and the PA were divided into seven plots (replications) of $400 \mathrm{~m}^{2}(20 \times 20 \mathrm{~m})$, as described by Jesus et al. (2016), totaling 42 plots. The number of plots was defined by a collector curve (RODAL; SAMPAIO; FIGUEIREDO, 2013). The predominant Normalized Difference Vegetation Index (NDVI) of each treatment was used to randomly allocate the plots.

The circumference at breast height $(\mathrm{CBH})$ (1.3 $\mathrm{m}$ from the ground) of live and dead plants with $\mathrm{CBH} \geq 6 \mathrm{~cm}$ (which could be used as energy source) was measured in each sampling plot. Protected, preserved and cacti plants were not part of the ESAB. The ESAB of each plant was determined using Equation 1 (SAMPAIO; SILVA, 2005), and converted to $\mathrm{Mg} \mathrm{ha}^{-1}$. The equivalent diameter was first calculated for multibranch trees (JESUS et al., 2016).

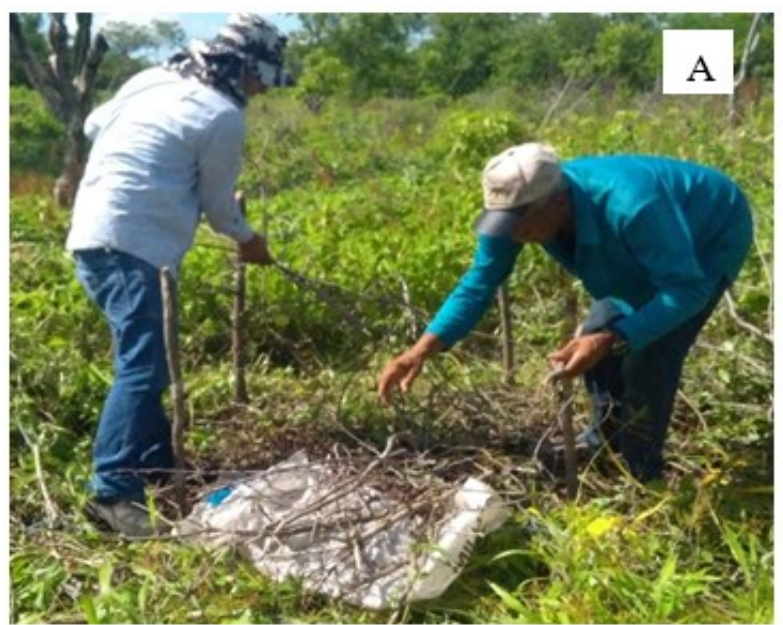

$$
\mathrm{ESAB}=0.173 * \mathrm{DAP}^{2.295}
$$

where ESAB is the explorable shrubby-arboreous biomass of each tree $(\mathrm{kg})$ and DAP is the diameter at breast height $(\mathrm{cm})$.

The mean original biomass stocks (MOBS) (Treatment 7) consisted of ESAB data sampled in 13 plots, which supported the implementation of the forest management in 2002 (VERDE VIDA, 2010). The ESAB mean annual increase (ESAB-MAI) of the areas in regeneration and the PA was determined by dividing the ESAB by the respective number of years in regeneration.

The second stage was carried out in a recently explored area (one month of exploration). The remaining biomass, which is composed of biomasses from branches and stumps (Figure 4) was determined in this area after the exploration.

The biomass of branches (Figure 4A) were evaluated in samples of seven plots $(1.0 \times 1.0 \mathrm{~m})$ considering the piles formed with plant residues of the exploration. The litterfall accumulated biomass on the soil of this area was also determined. The plant residues (biomass of branches and litterfall) of each plot were collected and weighed in the field. Part of the material collected was taken to the laboratory of Federal University of Ceará and dried in a forced air-circulation oven at $65{ }^{\circ} \mathrm{C}$ until constant weight to determine the dry biomass.

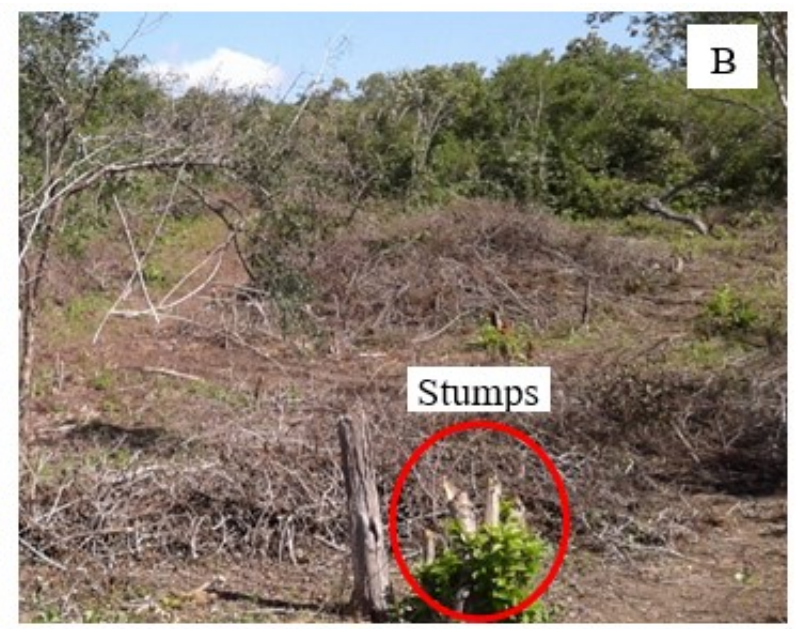

Figure 4. Example of remaining biomass of branches (A) and stumps (B).

The biomass of the stumps (Figure 4B) was determined by calculating the cylindrical volume (Vol) of each stump (Equation 2). The mean stump height (h) was $30 \mathrm{~cm}$, determined in a sample of 104 stumps ( $\mathrm{t}$ test). The area (a) of each stump was determined through the diameter measured in the 13 plots sampled. The form factor (ff) adopted was 0.9 (ZÁKIA; PAREYN; RIEGELHAUPT, 1992). The biomass of each stump (BC) was calculated using (Equation 3), multiplying the Vol by the mean density (md) of the wood $\left(0.69 \mathrm{~g} \mathrm{~cm}^{-3}\right)$ (CARVALHO; OLIVEIRA, 1994) and converting it to $\mathrm{Mg} \mathrm{ha}^{-1}$.

$$
\begin{aligned}
& \mathrm{Vol}=\mathrm{h} * \mathrm{a} * \mathrm{ff} \\
& \mathrm{BC}=\mathrm{Vol} * \mathrm{md}
\end{aligned}
$$

The third stage was carried out with estimations of remaining biomass and litterfall 
contributions to soil carbon stocks. The biomass of each plant part was multiplied by the respective carbon percentage of the biomasses- 0.45 for branches (VIEIRA et al., 2009), 0.45 for stumps, and 0.43 for litterfall (PEREIRA JÚNIOR et al., 2016).

Statistically, the first stage was conducted under a completely randomized block experimental design, with seven treatments: six areas in regeneration and one PA with seven replications, and a control (MOBS) with 13 replications. The data sampled presented normal distribution by the Shapiro-Wilk test. The data were subjected to analysis of variance (ANOVA) and the means were compared by the Tukey's test $(p \leq 0.05)$. The ESAB were compared according to their diameter classes; in this case, there was no normal distribution of the data, requiring the application of the Kruskal-Wallis test $(p \leq 0.05)$. The ESAB-MAI that presented normality by the Shapiro-Wilk test were subjected to analysis of variance (ANOVA) and the means were compared by the Tukey's test $(p \leq 0.05)$.

The mean biomass and carbon in the plant parts (branches, stumps, and litterfall) were compared in the second and third stages, by the Student's $\mathrm{t}$ test $(p \leq 0.05)$, after tested for normality by the Shapiro-Wilk test. Then, the total of remaining biomass was obtained by summing the mean biomasses of stumps and branches. All statistical analysis was done using the SPSS 16.0 program.

\section{RESULTS AND DISCUSSION}

The vegetation presented explorable shrubbyarboreous biomass (ESAB) accumulation throughout the regeneration time (Figure 5). The ESAB after three $\left(4.90 \pm 2.07 \mathrm{Mg} \mathrm{ha}^{-1}\right)$ and five $(16.11 \pm 5.90 \mathrm{Mg}$ $\left.\mathrm{ha}^{-1}\right)$ years were not significantly different $(\mathrm{p} \leq 0.05)$, although the biomass after five years increased 3.2fold. The ESAB found after eight years of regeneration $\left(30.03 \pm 7.13 \mathrm{Mg} \mathrm{ha}^{-1}\right)$ was not significantly different than that after 5 , and 11 years (39.17 $\left.\pm 13.12 \mathrm{Mg} \mathrm{ha}{ }^{-1}\right)$, expressing an ESAB accumulation over the evaluation periods. The ESAB after $11\left(39.17 \pm 13.12 \mathrm{Mg} \mathrm{ha}^{-1}\right)$ and 15 $\left(53.80 \pm 18.24 \mathrm{Mg} \mathrm{ha}^{-1}\right)$ years were similar to the mean original biomass stocks (MOBS) $(42.35 \pm 15.27$ $\left.\mathrm{Mg} \mathrm{ha}{ }^{-1}\right)$; however, significantly different biomass was found in after 40 years $\left(79.33 \pm 14.39 \mathrm{Mg} \mathrm{ha}^{-1}\right)$.

Statistically, the MOBS was reached 7 years before the cut cycle (15 years) commonly adopted for the management of these forests. Considering the vegetation MOBS recovery as a criterion for new cut cycle, it can be decreases from 15 (initial estimate) to 11 years, and up to 8 years. However, the vegetation was still young in these two treatments ( 8 and 11 years), with greater amount of biomass in the first diameter class $(2-5.99 \mathrm{~cm})$ than the other treatments, and significantly differing from the treatments with 15 years, MOBS, and 40 years (Figure 6A).

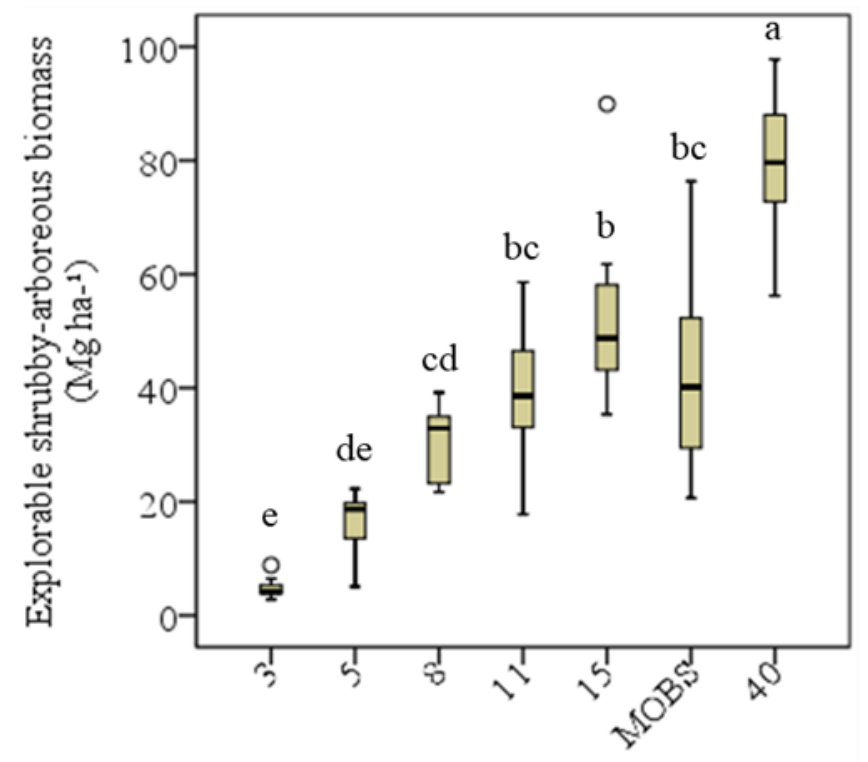

Years in regeneration and $M O B S$

Figure 5. Explorable shrubby-arboreous biomass (ESAB) throughout the regeneration time in a managed forest area with tropical dry forests of the Caatinga phytogeographic domain areas with $3,5,8,11,15$, and 40 years (preservation area) years of regeneration; and mean original biomass stocks (MOBS). Bars with different letters are not different by the Tukey's test $(\mathrm{p} \leq 0.05) ;{ }^{\circ}=$ Outliers. 
Biomasses of lower diameter classes $(2-5.99$ $\mathrm{cm}$ and 6-10.99 $\mathrm{cm}$ ) represented $73 \%$ and $75 \%$, respectively, (Figure 7) of the total biomass in the treatments with 8 and 11 years; whereas it was $47 \%$ and $26 \%$, respectively, for treatments with 15 and 40 years. Thus, an early cut after 8 or 11 years would result in a greater amount of low- quality biomasses (thin stems), causing losses in energetic efficiency due to the lower calorific power of the thin stems, which predominate in the younger treatments (YAN; XU: HE, 2018; ZENG; TANG; XIAO, 2014).

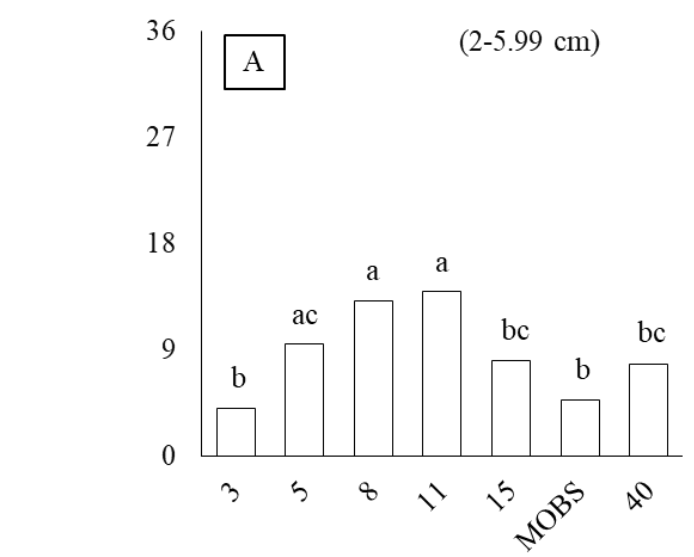

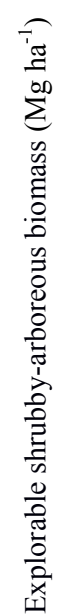

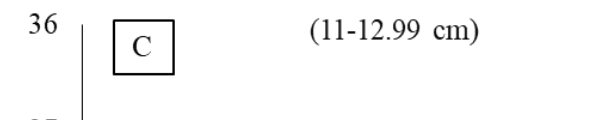

27

18

9

0
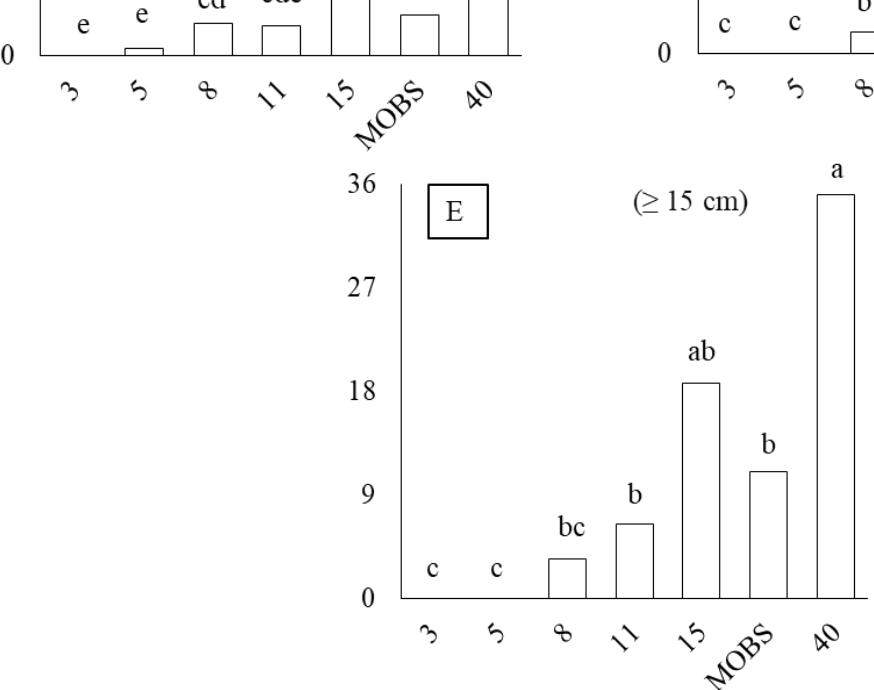

Years in regeneration and MOBS

$\geq 15 \mathrm{~cm})$
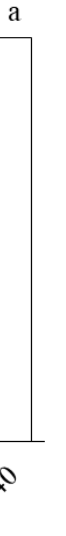

The MOBS recovery as a criterion to define a new cut cycle indicated an intermediate time between 11 and 15 years, which presented 62\% biomass in the two first diameter classes (Figure 7). However, the MOBS was significantly different than the treatment with 40 years in ESAB (Figure 5), and biomass in the three largest diameter classes (Figures $6 \mathrm{C}, 6 \mathrm{D}$, and $6 \mathrm{E})$. Thus, the MOBS do not correspond to the maximum ESAB possible for this area, confirming the results of Riegelhaupt, Pareyn, and Gariglio (2010), who questioned the use of this criterion due to the absence of vegetation maturity in terms of biomass accumulation.
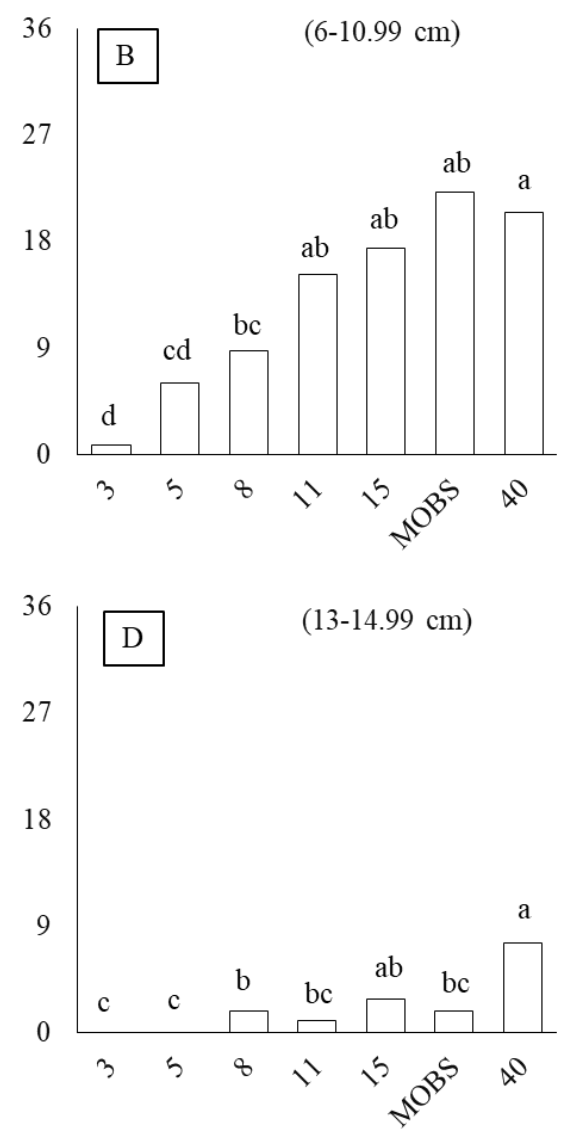

$$
\text { (n) }
$$

Figure 6. Explorable shrubby-arboreous biomass (ESAB) by diameter classes in a managed forest area with tropical dry forests of the Caatinga phytogeographic domain areas with 3, 5, 8, 11, 15, and 40 years (preservation area) years of regeneration; and mean original biomass stocks (MOBS). Bars with different letters are not different by the Kruskal-Wallis test $(\mathrm{p} \leq 0.05)$.

Rev. Caatinga, Mossoró, v. 33, n. 3, p. 735 - 745, jul. - set., 2020 


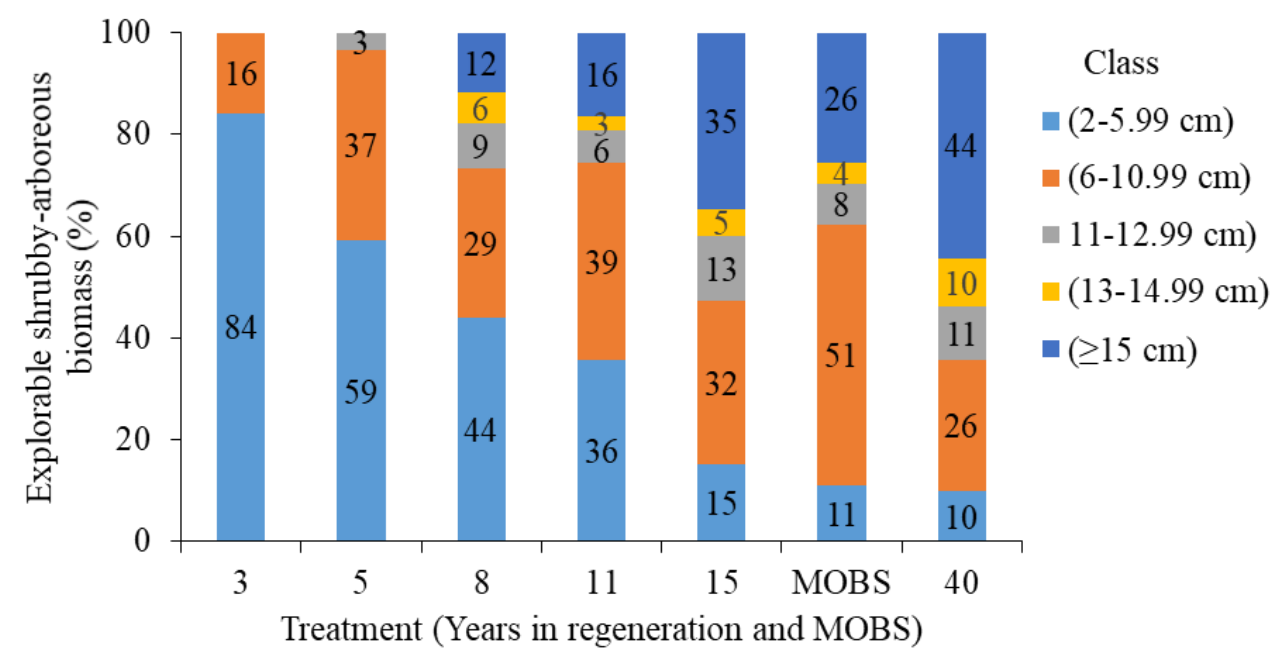

Figure 7. Percentual participation of each diameter class in the explorable shrubby-arboreous biomass (ESAB) in a managed forest area with tropical dry forests of the Caatinga phytogeographic domain areas with 3, 5, 8, 11, 15, and 40 years (preservation area) years of regeneration; and mean original biomass stocks (MOBS).

Moreover, this criterion is questionable due to the uncertainty about the succession stage of the area initially sampled that originated the MOBS; it could be a young area at the $3^{\text {rd }}$ or $4^{\text {th }}$ stage of secondary progressive succession (RIEGELHAUPT; PAREYN; GARIGLIO, 2010). This uncertainty occurred by observing the vegetation youngness at the sampling for the project, at least in some plots. The MOBS (Figure 5) present the highest amplitude $\left(55.68 \mathrm{Mg} \mathrm{ha}^{-1}\right.$ ), varying from $20.65 \mathrm{Mg} \mathrm{ha}^{-1}$ to $76.33 \mathrm{Mg} \mathrm{ha}^{-1}$, showing that the sampled areas were initially at different regeneration stages. There were younger areas with low biomass stocks and older areas with high biomass stocks, confirming the rejection of this criterion to define the time for a new cut cycle.
Therefore, the cut cycle should not be based only on the total biomass, but also on the biodiversity of species, and stem diameters. When these two other factors cannot be considered, the management may be unsustainable, with loss of biodiversity.

The explorable shrubby-arboreous biomass mean annual increase (ESAB-MAI) (Figure 8) was not determined for the MOBS, because the project data, which was the source of information of MOBS, did not include the age of the plots sampled. The lowest ESAB-MAI was found for the treatment with 3 years $\left(1.63 \pm 0.69 \mathrm{Mg} \mathrm{ha}^{-1} \mathrm{yr}^{-1}\right)$ and the highest for 5 $\left(3.22 \pm 1.18 \mathrm{Mg} \mathrm{ha}^{-1} \mathrm{yr}^{-1}\right)$ and $15\left(3.59 \pm 1.21 \mathrm{Mg} \mathrm{ha}^{-1}\right.$ $\left.\mathrm{yr}^{-1}\right)$ years, with a peak at 8 years $\left(3.75 \pm 0.89 \mathrm{Mg} \mathrm{ha}^{-1}\right.$ $\left.\mathrm{yr}^{-1}\right)$.

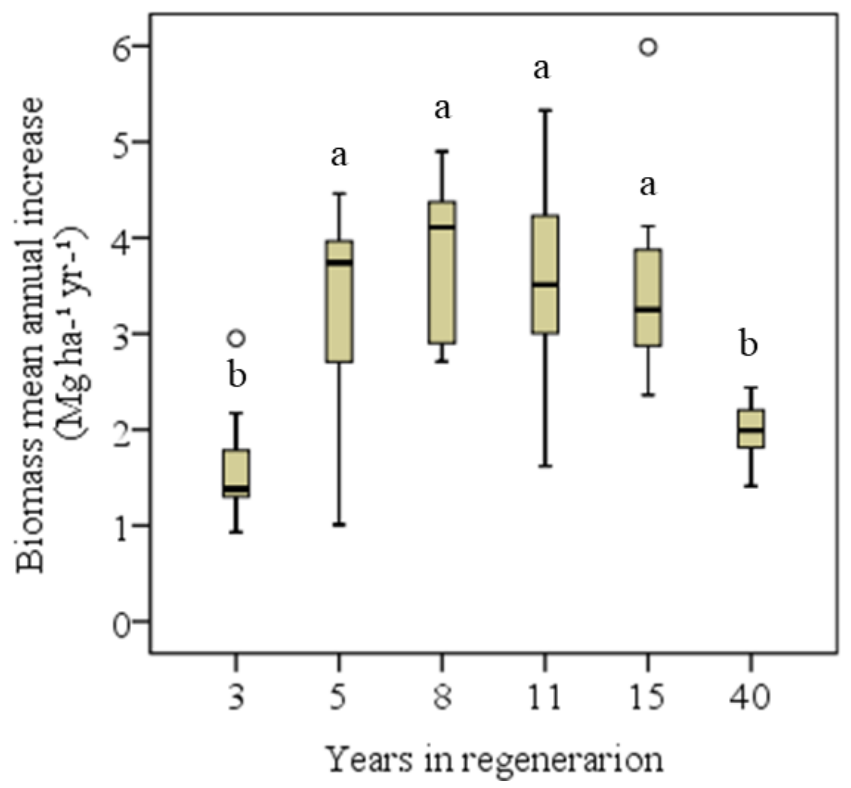

Figure 8. Explorable shrubby-arboreous biomass mean annual increase (ESAB-MAI) throughout the regeneration time in a managed forest area with tropical dry forests of the Caatinga phytogeographic domain areas with $3,5,8,11,15$, and 40 years (preservation area) years of regeneration. Bars with different letters are not different by the Tukey's test $(\mathrm{p} \leq 0.05) ;^{\circ}=$ Outliers.

Rev. Caatinga, Mossoró, v. 33, n. 3, p. 735 - 745, jul. - set., 2020 
The ESAB-MAI decreased after 8 years; however, without significant difference in the period of 5 to 15 years. Contrastingly, it decreased after 40 years $\left(1.98 \pm 0.36 \mathrm{Mg} \mathrm{ha}^{-1} \mathrm{yr}^{-1}\right)$, differing significantly from the areas with 5 to 15 years. The low increase after 3 and after 40 years, which were similar but differed from the other treatments, are due to different reasons. Not all plants reached $6 \mathrm{~cm}$ circumference to be included after three years; and the biomass accumulation rate of the mature vegetation was decreasing after 40 years (ARAÚJO FILHO, 2013).

The ESAB-MAI found were, in general, similar to those reported by Riegelhaupt, Pareyn, and Bacalini (2010) for TDF-CPD areas in Sobral, CE, Brazil, and higher than those found for the areas in the state of Rio Grande do Norte, Brazil. Moreover, the ESAB-MAI found were lower than those found for two managed forest areas in the municipalities of Caucaia and Pacajus, CE, Brazil.

The lower ESAB-MAI found was due to the lower mean rainfall depths of the General Sampaio region when compared to those of the municipalities of Pacajus and Caucaia. These municipalities are in the state coastal region and present $30 \%$ and $77 \%$ higher rainfall depths than General Sampaio, respectively, and consequently a higher water available for the vegetation growth. The interactive dynamics of determinant factors for biomass production in a same forest types may result in different responses from one place to another, which requires further studies to better understand these factors as determining of vegetation regeneration.

Considering the different results found in the literature, the little information on vegetation regeneration based on the whole forest, the large diversity of environments, the intrinsic factors of each managed forest (soil, rainfall, and species), even when dealing with tropical dry forests, longer cut cycles should be adopted. The cycle of 15 years commonly adopted for managed areas of TDF-CPD does not seem sustainable because the vegetation will be still relatively young.

The ESAB (Figure 5) and ESAB-MAI (Figure 8 ) of the treatment with 15 years differed from the treatment with 40 years (PA), whose vegetation already showed a certain maturation. In addition, almost half of the ESAB (Figure 7) after 15 years was in the two first diameter classes, showing the youngness of the vegetation.

Therefore, the cut cycle is better defined by considering not a specific period, a fixed cycle as currently used, or the recovery of the MOBS, as shown in the present study. The previous sampling of the area provides important information about the ESAB distribution by diameter class (Figures 6 and 7 ), and the biodiversity by identifying the species, showing the vegetation regeneration stage of this area by species. This survey can show which products (firewood, stakes, poles, low-quality charcoal, good-quality charcoal) can be obtained from the vegetation at a time, allowing to choose biomasses of greater diameter classes.

The use of this criterion allows a better balanced use of forest resources of TDF-CPD, since it can be explored when reaching a regeneration stage with greater stem diameters, and provide a better financial return because of the obtaining of more valuable products, such as stakes, poles, and good-quality charcoal. When some species are not found, or predominate over others, the adoption of a selective cut can be better to inhibit dominant species and introduce others that are absent or at very low densities. The exploration of plants of higher diameter classes, and biodiversity evaluation are criteria that can define cut cycles in managed areas of TDF-CPD and enable a more rational exploration of forest resources.

The remaining biomass of branches varied from 9.56 to $23.18 \mathrm{Mg} \mathrm{ha} \mathrm{ha}^{-1}$, with mean of $18.03 \pm 4.38 \mathrm{Mg} \mathrm{ha}^{-1}$ (Figure 9). The biomass of stumps was significantly lower (t test $p \leq 0.05$ ) than the biomass of branches, varying from $1.42 \mathrm{Mg} \mathrm{ha}^{-1}$ to $6.21 \mathrm{Mg} \mathrm{ha}^{-1}$, with mean of $3.28 \pm 1.47 \mathrm{Mg} \mathrm{ha}^{-1}$.

The remaining biomass totaled $21.31 \mathrm{Mg} \mathrm{ha}^{-1}$, higher than that found by Lopes and Andrade (2017) (7.6 Mg ha ${ }^{-1}$ ) based on secondary data of a management area of TDF-CPD, but with similar estimated biomass. This difference may be due to limitations in the evaluation due to the use of secondary data in that study.

The purpose of the biomass extracted also explains this difference. When the purpose is charcoal production plant parts with greater diameters are preferred, resulting in more residues in the area. The charcoal produced with thinner branches are more susceptible to break (SILVA, 1988), and minimum losses by transporting are required when it is intended to domestic and commercial uses (FROEHLICH; MOURA, 2014). When the purpose is firewood extraction, branches of up to $2 \mathrm{~cm}$ diameter are extracted (VERDE VIDA, 2010), which resulted in less remaining biomass in the recently explored area. Achat et al. (2015) analyzed 168 studies on consequences of intense forest harvesting and found that a highintensity harvesting with removal of whole trees, including branches, in general, impacts negatively the soil properties and the forest ecosystem functioning, and are even more damaging when the leaves are also removed from the area.

The accumulated litterfall varied from 1.52 to $9.13 \mathrm{Mg} \mathrm{ha}^{-1}$, with mean of $5.55 \pm 2.56 \mathrm{Mg} \mathrm{ha}^{-1}$. Salgado et al. (2015) found similar results, with 5.93 to $6.12 \mathrm{Mg} \mathrm{ha}^{-1}$ of litterfall in a preservation area of TDF-CPD in General Sampaio, CE, Brazil. Lopes et al. (2009) evaluated an area with TDF-CPD in regeneration for 30 years and found lower accumulated litterfall $\left(4.02 \mathrm{Mg} \mathrm{ha}^{-1}\right)$. The results indicate that the litterfall production is affected by 
regeneration time, even after three decades, showing the need for further studies on the time required for a cut cycle in a TDF-CPD. According to Araújo Filho
(2013), the arboreous is predominant over the shrubby stratum only after 45 years.

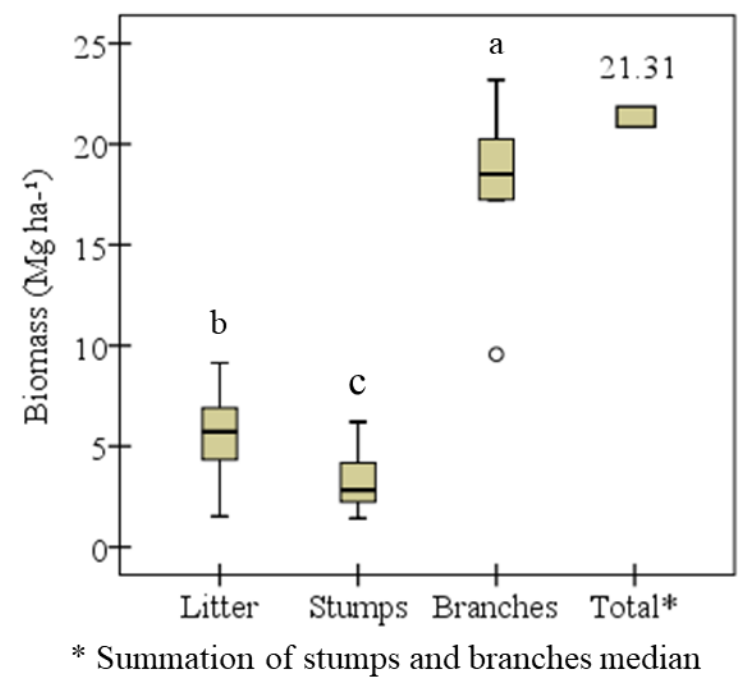

Figure 9. Biomass before the exploration (litterfall), and remaining biomass (stumps and branches) after extraction of wood for charcoal production in a tropical dry forest of the Caatinga phytogeographic domain. Bars with different letters are not different by the $\mathrm{t}$ test $(\mathrm{p} \leq 0.05) ;{ }^{\circ}=$ Outliers.

The litterfall accumulated in the managed areas has significant contribution of branch biomasses $\left(18.03 \pm 4.38 \mathrm{Mg} \mathrm{ha}^{-1}\right)$, increasing in more than 3.0 -fold the litterfall in the areas. This biomass of branches is arranged in piles that covered $60 \%$ (Figure 3) of the explored area in this management. This large increase of biomass to the soil surface should attenuate erosive processes after the forest exploration and maintain a higher soil moisture (ANDRADE et al., 2019), assisting in the biological activity and favoring the cycling of nutrients.

The biomass of branches found was lower than those found for the Amazon Forest $\left(38 \mathrm{Mg} \mathrm{ha}^{-1}\right)$ by Cruz Filho and Silva (2009) because of the different edaphoclimatic conditions of the Semiarid region. Moreover, the Amazon Forest area in that study was managed with technics to decrease impacts, preserving many trees; if the clearcutting technic was used, the remaining biomass would be well above $38 \mathrm{Mg} \mathrm{ha}^{-1}$. Webster et al. (2016) found a quantity of residues produced by pine forests after harvest of approximately $27 \mathrm{Mg} \mathrm{ha}^{-1}$, in Canada.

The potential contribution of the biomasses to soil carbon stocks (Figure 10) by the cycling of thin branches in the area (Figures 3 and 4A) was $8.06 \mathrm{Mg}$ $\mathrm{ha}^{-1}, 3.4$-fold higher that of the litterfall, which is a fraction that naturally cycle carbon and nutrients. This contribution represents approximately $71 \%$ of the carbon stocks $\left(11.29 \mathrm{Mg} \mathrm{ha}^{-1}\right)$ in the first $10 \mathrm{~cm}$ of Luvisols with preserved vegetation in this forest (VALBRUN et al., 2018). Guedes et al. (2018) found that the great litterfall production resulted in higher amount of carbon added to the soil in a planted forest of 34 years with eucalyptus and pines when compared to neighboring native forest areas that were more susceptible to fire and illegal cuts.

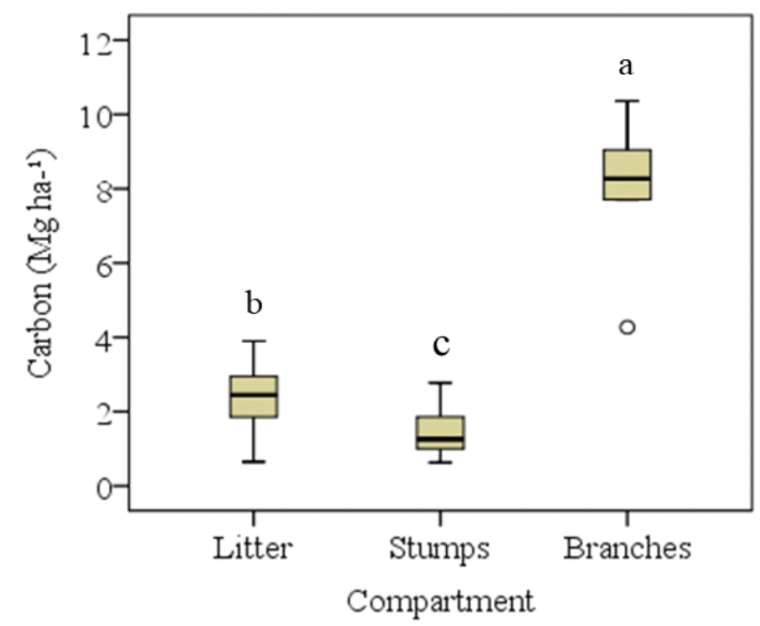

Figure 10. Carbon stocks in plant parts (litterfall, stumps, and branches). Bars with different letters are not different by the $t$ test $(\mathrm{p} \leq 0.05) ;{ }^{\circ}=$ Outliers.

Rev. Caatinga, Mossoró, v. 33, n. 3, p. 735 - 745, jul. - set., 2020 
The contribution of branches to soil carbon stocks is highlighted, since the litterfall was present in the area before the management, and most stumps will originate new plants without senescence. The results evidenced the need for decision-makers to focus on improving cut cycles to favor biomass production without compromising the biodiversity.

\section{CONCLUSIONS}

The results found for the explorable shrubbyarboreous biomass and remaining biomass of the evaluated tropical dry forest in the Caatinga phytogeographic domain showed that the recovery of the mean original biomass stocks of an area after clearcutting should not be the criterion to define a new cut cycle, since these original stocks do not necessarily represent the maximum possible biomass production in the area. The evaluation of the biodiversity and the presence of biomass of greater diameter classes are more adequate criteria to define cut cycles for these forests. The remaining biomass of the branches had more biomass than the other plant parts and, consequently, greater contribution to soil carbon stocks, followed by the litterfall and stumps. The carbon stock in the branches was 3.4fold higher than that in the litterfall.

\section{ACKNOWLEDGEMENTS}

The authors thank the Brazilian National Council for Scientific and Technological Development (CNPq), the Brazilian Institute for Colonization and Agrarian Reform (INCRA), and the Graduation Program in Agricultural Engineering of the Federal University of Ceará (PPGEA/UFC) for the financial support; the Environmental Superintendence of the State of Ceará (SEMACE) for providing the original project; and the Ramalhete Settlement Association for the concession of the study area and friendly reception.

\section{REFERENCES}

ACHAT, D. L. et al. Quantifying consequences of removing harvesting residues on forest soils and tree growth - a meta-analysis. Forest Ecology and Management, 348: 124-141, 2015.

ANDRADE, E. M. et al. Procesos ecohidrológicos y servicios ecosistémicos em regiones secas. Cuadernos de la Sociedad Española de Ciencias Forestales, 45: 241-250, 2019.

ANDRADE, E. M. et al. Uncertainties of the rainfall regime in a tropical semi-arid region: the case of the
State of Ceará. Revista Agro@mbiente On-line, 10: 88-95, 2016.

ARAÚJO FILHO, J. A. Manejo pastoril sustentável da caatinga. 1. ed. Recife, PE: Projeto Dom Helder Câmara, 2013. 200 p.

BRAZ, R. L. et al. Resíduos da colheita florestal e processamento da madeira na Amazônia - uma análise da cadeia produtiva. Journal of Biotechnology and Biodiversity, 5: 168-181, 2014.

CARVAlHO, A. J. E.; OLIVEIRA, C. R. Avaliação do estoque lenhoso: inventário florestal do Estado do Ceara. 1. ed. Fortaleza, CE: PNUD/FAO/ IBAMA/SDU/SEMACE, 1994. 61 p. (Documentos de Campo, 26).

CRUZ FILHO, D.; SILVA, J. N. M. Avaliação da quantidade de resíduos lenhosos em floresta não explorada e explorada com técnicas de redução de impactos, utilizando amostragem por linha interceptadora, no Médio Mojú, Amazônia Oriental, Brasil. Acta Amazonica, 39: 527-532, 2009.

FROEHLICH, P. L.; MOURA, A. B. D. Carvão vegetal: propriedades físico-químicas e principais aplicações. Tecnologia e Tendências, 9: 13-32, 2014.

GUEDES, B. S. et al. Net primary production in plantations of Pinus taeda and Eucalyptus cloeziana compared with a mountain miombo woodland in Mozambique. Global Ecology and Conservation, 15: e00414, 2018.

HUANG, J. et al. Accelerated dryland expansion under climate change. Nature Climate Change, 2: 166-171, 2015.

JESUS, K. N. et al. Guia metodológico para o desenvolvimento de atividades de campo e laboratório do projeto CNPQ rede - C - NE. Recife, PE: UFPE, 2016. 35 p. (Relatório Técnico).

LOPES, J. F. B.; ANDRADE, E. M. Biomassa remanescente em plano de manejo florestal da caatinga, manejado sob corte raso. In: III SIMPÓSIO BRASILEIRO DE RECURSOS NATURAIS DO SEMIÁRIDO, n. 3, 2017, Fortaleza. Anais... Fortaleza: MASSA, 2017. p. 1-6.

LOPES, J. F. B. et al. Deposição e decomposição de serapilheira em área da Caatinga. Agro@mbiente on-line, 3: 72-79, 2009.

MILES, L. et al. A global overview of the conservation status of tropical dry forests. Journal of Biogeography, 33: 491-505, 2006. 
MORO, M. F. et al. Phytogeographical Metaanalysis of the Semiarid Caatinga Domain in Brazil. The Botanical Review, 82: 91-148, 2016.

PEREIRA JÚNIOR, L. R. et al. Carbon stocks in a tropical dry forest in Brazil. Revista Ciência Agronômica, 47: 32-40, 2016.

RIEGELHAUPT, E.; PAREYN, F. G. C.; GARIGLIO, M. A. O manejo florestal como ferramenta para o uso sustentável e conservação da caatinga. In: GARIGLIO, M. A. et al. (Eds.). Uso sustentável e conservação dos recursos florestais da caatinga. Brasília, DF: Serviço Florestal Brasileiro, 2010. v. 1, cap. 24, p. 349-367.

RIEGELHAUPT, E.; PAREYN, F. G. C.; BACALINI, P. O manejo florestal na caatinga: resultados da experimentação. In: GARIGLIO, M. A. et al (Eds.). Uso sustentável e conservação dos recursos florestais da caatinga. Brasília, DF: Serviço Florestal Brasileiro, 2010. v. 1, cap. 17, p. 256-275.

RODAL, M. J. N. F.; SAMPAIO, E. V. S. B.; FIGUEIREDO, M. A. Manual sobre métodos de estudos florísticos e fitossociológicos - ecossistema caatinga. 1. ed. Brasília, DF: Sociedade Botânica do Brasil, 2013. 24 p.

SALGADO, E. V. et al. Rainfall patterns and the contribution of litter in the caatinga dry tropical forest. Revista Ciência Agronômica, 46: 299-309, 2015.

SAMPAIO, E. V. S. B.; SILVA, G. C. Biomass equations for Brazilian semiarid Caatinga plants. Acta Botanica Brasilica, 19: 935-943, 2005.

SILVA, D. A. Qualidade do carvão vegetal produzido com madeiras na região de Manaus em fornos de alvenaria. Acta Amazônica, 18: 163-178, 1988.

SORENSEN, L. A. Spatial Analysis Approach to the Global Delineation of Dryland Areas of Relevance to the CBD Programme of Work on Dry and Sub-Humid Lands. UNEP World Conservation Monitoring Centre, 2009, 65 p.

VALBRUN, W. et al. Carbon and nitrogen stock under different types of land use in a seasonally Dry Tropical Forest. Journal of Agricultural Science, 10: 479-492, 2018.

VERDE VIDA. Reformulação de plano de manejo agrossilvipastoril de Ramalhete. 1. ed. Fortaleza, CE: Verde Vida Engenharia Ambiental, 2010. 121 p. (Relatório Técnico).
VIEIRA, G. et al. Teores de carbono em espécies vegetais da Caatinga e do Cerrado. Revista Acadêmica: Ciências Agrárias e Ambientais, 7: 145-155, 2009.

WEBSTER, K. L. et al. Soil CO2 efflux and net ecosystem exchange following biomass harvesting: Impacts of harvest intensity, residue retention and vegetation control. Forest Ecology and Management, 360: 181-194, 2016.

YAN, P.; XU, L.; HE, N. Variation in the calorific values of different plants organs in China. Revista PloS One, 13: 1-14, 2018.

ZÁKIA, M. J. B.; PAREYN, F. G.; RIEGELHAUPT, E. Equações de peso e de volume para oito espécies lenhosa nativas do Seridó, RN. In: IBAMA. Plano de manejo florestal para a região do Seridó do Rio Grande do Norte. Natal, RN: PNUD / FAO / IBAMA - Governo do Rio Grande do Norte, 1992. v. 1, cap. 4, p. 1-92.

ZENG, W. S.; TANG, S. Z.; XIAO, Q. H. Calorific values and ash contents of different parts of Masson pine trees in southern China. Journal of Forestry Research, 25: 779-786, 2014. 